\title{
Language Matters: Considering Microaggressions in Science
}

\section{Colin Harrison ${ }^{\dagger}$ and Kimberly D. Tanner**}

'School of Biological Sciences, Georgia Institute of Technology, Atlanta, GA 30332; " Department of Biology, San Francisco State University, San Francisco, CA 94132

anguage matters. What we say can have profound effects on an individual's sense - of belonging, self-efficacy, and science identity. Think back to a time when you felt slighted or invalidated by something that was said to you. Were you upset? Angry? Confused? Did you doubt yourself? Were you uncertain how to respond? To what extent did one small comment dominate your thoughts or interfere with other tasks you were trying to accomplish? Now imagine this slight occurred in an area where you aspired to have success: in your research laboratory, in a classroom, during a conference, or in a faculty meeting. How does such language affect your ability to concentrate on your professional and academic responsibilities in these environments?

Similarly, we can ourselves use language that may slight or invalidate someone else, even with only the best of intentions. We all make mistakes and may lack awareness of the way our words may affect those around us. We also all have unconscious biases that influence how we interact with one another. While we may or may not be aware of, or effectively address, biases, they are a part of everyday life for nearly all humans. And these biases exist regardless of the view that science and scientists are somehow supposed to be rational, objective, and unbiased. As scientific professionals, we must recognize that our own conscious and unconscious biases, and language related to them, may have large impacts on our students and colleagues. One of the ways that these biases can manifest is in our language, through the use of microaggressions. Here, we use the term "microaggressions" to refer to brief, sometimes subtle, everyday exchanges that either consciously or unconsciously disparage others based on their personal characteristics or perceived group membership (Pierce et al., 1978; Sue, 2010).

Microaggressions have moved into the popular lexicon recently, and more people are becoming aware of their existence in both personal and professional contexts. Colleges around the country are increasingly becoming more attentive to microaggressions in the culture of higher education and to the effects of microaggressions on the students and faculty at their institutions (Zamudio-Suarez, 2016). The backlash against microaggressions has been just as widespread. For example, when a document about microaggressions issued by the University of California at Berkeley was recently disseminated among the public, there were cries against the "politically correct police" coming to take free speech away (Times Editorial Board, 2015). No doubt, all situations involving language and bias are complex, but a thoughtful exploration of microaggressions is currently warranted, because microaggressive language may be a key variables that is influencing the experiences, persistence, and success of all students in higher education, especially students currently underrepresented in the sciences.

Science can be an isolating and psychologically challenging field for many young scholars who embark upon a scientific career. While some efforts have helped improve the climate for students on some campuses, and strides have been made in increasing access and diversity in science, low retention rates in the sciences and the scarcity of women and people of color in leadership positions show that there is much work to be done in creating a safe and welcoming scientific environment for all (Blickenstaff, 2005; Moss-Racusin et al., 2012; Morley, 2013; Chang et al., 2014). One way in which
CBE Life Sci Educ March 1, 2018 17:fe4 DOI:10.1187/cbe.18-01-0011

*Address correspondence to: Kimberly D. Tanner (kdtannerasfsu.edu).

(C) 2018 C. Harrison and K. D. Tanner. CBE-Life Sciences Education (c) 2018 The American Society for Cell Biology. This article is distributed by The American Society for Cell Biology under license from the author(s). It is available to the public under an Attribution-Noncommercial-Share Alike 3.0 Unported Creative Commons License (http://creativecommons.org/licenses/ by-nc-sa/3.0)

"ASCB ${ }^{\circledR "}$ and "The American Society for Cell Biology ${ }^{\circledR "}$ are registered trademarks of The American Society for Cell Biology. 
we can help to improve this climate is to begin addressing microaggressions where they appear in professional scientific contexts. Microaggressions have been studied extensively in fields such as psychology and business, but little has been investigated about how microaggressions may manifest in science settings. Here, we explore how microaggressions may specifically occur in science and bring to light some of the challenges that they may precipitate.

\section{WHAT ARE MICROAGGRESSIONS?}

The term "microaggression" was first coined in 1978 by Chester M. Pierce to describe a phenomenon of subtle negative exchanges directed toward African Americans (Pierce et al., 1978). While the idea of microaggressions has been around for decades, it has only more recently come to the forefront in psychology (Sue, 2010). Whereas overt forms of discrimination may be more easily identified, subtle discrimination has received increased attention focused on studying how it may affect individuals in society, especially those from groups that have been historically marginalized. Microaggressions can be related to race, gender, sexual orientation, socioeconomic status, religion, or other features that reflect some aspect of personal identity. And while microaggressions most often present as verbal slights in spoken language, they may also take on nonverbal or environmental forms.

\section{EXPLORING CATEGORIES OF MICROAGGRESSIONS: MICROASSAULTS, MICROINSULTS, AND MICROINVALIDATIONS}

Scholars have proposed three categories of microaggressions that can occur in everyday interactions: microassaults, microinsults, and microinvalidations. In which category a particular microaggression may fall usually depends on the context surrounding the microaggression, as well as the effect this language has on those who hear it. Here, we explore each of the three types of microaggressions. Then, we present two example scenarios-situated purposefully in scientific professional contexts-for each of these types of microaggressions. These examples, along with several additional examples, can also be found in Table 1.

\section{Microassaults: Definition and Examples}

Of the three types of microaggressions, microassaults are perhaps the easiest to identify and most closely related to outright prejudice and discrimination. Derald Wing Sue (2010, p. 28) describes microassaults as "conscious, deliberate and either subtle or explicit ... biased attitudes, beliefs, or behaviors that are communicated to marginalized groups through environmental cues, verbalizations, or behaviors." Below, we share two brief vignettes in scientific professional contexts that could be considered examples of microassaults, one related to sexual orientation and one related to religious beliefs.

Microassault: Dominique's Lab Meeting. Dominique's principal investigator (PI) is presenting an update on the state of research in lab meeting when one of her colleagues, Ruth, in reference to an experiment that is not working, exclaims, "It's so gay that we can't get this assay to work correctly." Dominique's PI seems oblivious to the microaggression and continues with the presentation. By using the term "gay" in a derogatory manner, Ruth is communicating a biased attitude toward individuals of a particular sexual orientation, which could have a strong negative affect on any LGBTQIA-lesbian, gay, bisexual, transgender, queer, intersex, and asexual —individual present, as an aspect of their personal identity is being portrayed

TABLE 1. Microaggressions in science examples (inspired by Sue et al., 2007)

\begin{tabular}{|c|c|c|}
\hline Type & Microaggression & Message \\
\hline \multirow[t]{4}{*}{ Microassault } & "It's so gay that we can't get this assay to work correctly." & Being gay is bad/abnormal. \\
\hline & $\begin{array}{l}\text { "Really, it's ridiculous that anyone believes in God, you can't be a real } \\
\text { scientist if you believe in God." }\end{array}$ & Religious people cannot be scientists. \\
\hline & $\begin{array}{l}\text { "You should do med school back in Mexico, because I don't think } \\
\text { people like you can succeed here." }\end{array}$ & Hispanic people cannot be successful in America. \\
\hline & $\begin{array}{l}\text { "It's a shame you are having kids in graduate school, you could have } \\
\text { really been something special" }\end{array}$ & $\begin{array}{l}\text { Women cannot have children and succeed in } \\
\text { science. }\end{array}$ \\
\hline \multirow[t]{4}{*}{ Microinsult } & $\begin{array}{l}\text { "I didn't do well, but, oh well, girls aren't supposed to be good at } \\
\text { science anyway, ha-ha." }\end{array}$ & Women cannot be good at science. \\
\hline & $\begin{array}{l}\text { "Is there any way you could dial back the accent a bit? It really makes } \\
\text { you sound unscientific." }\end{array}$ & You cannot have an accent and be a scientist. \\
\hline & $\begin{array}{l}\text { "You're the first Black person I have had in my bio classes, it must be } \\
\text { hard being an athlete and a biology major." }\end{array}$ & African Americans are only in school for athletics. \\
\hline & $\begin{array}{l}\text { "A plain white lab coat? But you're gay, so your lab coat should be } \\
\text { fabulous!" }\end{array}$ & All gay people dress a certain way. \\
\hline \multirow[t]{4}{*}{ Microinvalidation } & $\begin{array}{l}\text { "Race isn't an issue in our department, students just need to take } \\
\text { better advantage of the resources on campus." }\end{array}$ & Students' racial experiences do not matter. \\
\hline & $\begin{array}{l}\text { "The book is expensive, but it shouldn't be an issue. Just have your } \\
\text { parents pay for it." }\end{array}$ & $\begin{array}{l}\text { Students' financial situations are not an issue in } \\
\text { my class. }\end{array}$ \\
\hline & $\begin{array}{l}\text { "We only focus on males mating with females in this class because } \\
\text { that is all we care about in genetics." }\end{array}$ & $\begin{array}{l}\text { We do not care about nonheterosexual experi- } \\
\text { ences. }\end{array}$ \\
\hline & $\begin{array}{l}\text { "I don't believe Dr. Doe was being sexist with his comments, you're } \\
\text { blowing this out of proportion." }\end{array}$ & $\begin{array}{l}\text { You are being too sensitive, and I understand your } \\
\text { experience better than you. }\end{array}$ \\
\hline
\end{tabular}


negatively. By not responding, Dominique's PI also sets up an environment in the laboratory that tacitly allows the use of such language and that is unwelcoming to LGB individuals.

Microassault: Jay's Biotechnology Course. Jay is coteaching a biotechnology course that focuses on big breakthroughs in science with his colleague Anya. Jay had just been discussing the role of religion in the history of science, when Anya chimes in: "Really, it's ridiculous that anyone believes in God. You can't be a real scientist if you believe in God." When Anya uses this kind of language, she signals that she denies the science identity of anyone who may be religious. In a course context, this language can have damaging impacts on students' views of science and scientists, as well as on the instructor-student relationship.

\section{Microinsults: Definition and Examples}

Microinsults are described by Sue (2010, p. 31) as "characterized by interpersonal or environmental communications that convey stereotypes, rudeness, and insensitivity and that demean ... a person's identity." Unlike microassaults, microinsults are often committed unconsciously and may seem more subtle, yet still cast a negative light on a particular personal characteristic or demographic group. We share here two vignettes in scientific professional contexts that could be considered examples of microinsults, one related to gender and another related to native language.

Microinsult: Jorge's Exam. Jorge is teaching and has just handed back midterm exams for an introductory biology class. He hears a female student, Ashley, exclaim, “I didn't do well, but, oh well, girls aren't supposed to be good at science anyway, ha-ha." By espousing a negative stereotype about women in science, Ashley is not only being insensitive to her own identity, but she may also affect other female students around her. Microaggressions such as this microinsult do not always come from people outside an identified group and may be even more damaging coming from within the self-identified group (Murphy-Shigematsu, 2010; Nadal et al., 2011, 2013).

Microinsult: Jasmine's Graduate Seminar. Jasmine is one of several faculty members sitting in on a graduate seminar on presentation skills. It is Charles's turn to give his practice presentation and he has a thick Southern American English accent. At the end of the presentation, one of the other faculty members, Claire, makes the comment: "Is there any way you could dial back the accent a bit? It really makes you sound unscientific." Claire, by making this request of Charles, is sending the message that there is something abnormal about the way Charles speaks and that if he really wants to be a scientist, he will have to change this aspect of his personal identity, which is likely deeply connected to his home culture and family.

\section{Microinvalidation: Definition and Examples}

Microinvalidations, in the words of Sue (2010, p. 37), are "characterized by communications or environmental cues that exclude, negate, or nullify the thoughts, feelings, or experiential realities of certain groups." By questioning the accuracy and validity of another individual's personal experience, one is casting aside those experiences as being less relevant than one's own perceptions and experiences. We share two vignettes in scientific professional contexts that could be considered examples of microinvalidations, one related to race and ethnicity and another related to socioeconomic status.

Microinvalidation: Lisa's Faculty Meeting. Lisa is in a biology faculty meeting when the topic of Black students not feeling comfortable in biology classrooms is raised. The chair of the department asserts that a lack of belonging by Black students could not be an issue, because there are no issues with race in the department, and then goes on to suggest that the students just need to take better advantage of the resources on campus. This response seems to shut down any discussion, and several of Lisa's colleagues, including the only Black faculty member, look uncomfortable. By denying the realities of the Black students on campus, the biology chair is sending the message that the department does not take the concerns of this population of students seriously. It also sends a negative message to the Black faculty member, suggesting that the department may not be supportive if similar discussions are raised in relation to faculty issues.

Microinvalidation: John's Cellular Biology Course. John is sitting in the first day of cellular biology with his friend Chase. When discussing the expectations for the class, the professor, Amhad, says, "The book is expensive, but it shouldn't be an issue. Just have your parents pay for it." John knows Chase is paying for his education himself, because his parents do not have the finances to help, and John can tell Chase is immediately uncomfortable with the comment. By making this statement, Amhad is invalidating the feelings of Chase and maybe more students who are worried about their finances for school and simply may not have the familial resources that are being assumed by the instructor.

\section{ADVERSE EFFECTS OF MICROAGGRESSIONS}

But why does it matter if someone has aspects of their personal identity ridiculed, challenged, or dismissed? While we have shared the definitions of different types of microaggressions and offered some examples, microaggressions are a particularly complex topic to understand, especially if one does not have much personal experience with them. In particular, the psychological and emotional harm that they can precipitate may be hard to conceptualize. As such, we provide a brief analogy that may prove helpful to readers in considering research findings on the adverse effects of microaggressions.

Imagine someone pokes you with their finger. The physical impact of this poking on your body could range from mildly annoying to harmless depending on who is poking you and under what circumstances. If you are poked infrequently, you might not think much about it and not see being poked as such a big deal. However, when you are frequently and repeatedly poked, it may become tiresome, a distraction, and a burden. For example, you may start to become wary of others, because you do not know if the person coming up to speak with you after a conference might be about to poke you. If you happen to react negatively to someone who just poked you, because you happen to have been poked a lot that week, that person may assert that you are overreacting. You may even start to rationalize the poking as being justified and have negative feelings about yourself, because others have told you that being poked is trivial. 
We can even conceptualize the three different types of microaggressions in the context of this poking analogy. For a microassault, the person poking you may not care that it is affecting you or may have rationalized why they are doing it, even as they are consciously aware that they are poking you and that it has consequences. With microinsults, the person poking you may not even be aware they are poking you and may not be aware that their poking can have negative effects. Finally, with microinvalidations, the person may be poking you or know you are being poked, but may not think it matters or is a cause for concern.

In addition to the aforementioned negative effects, being poked can result in persistent problems. If you keep being poked in the same spot (i.e., hearing the same microaggression repeatedly), you could develop a bruise at that spot. Or if you already have an injury from another serious trauma, being poked in that spot may really hurt. Considering this analogy to being poked frequently and repeatedly may allow some to begin to see how repeated small events could accrue and lead to larger negative impacts on individuals. Importantly, all of these experiences could distract from a person's focus, concentration, and success in an academic setting. In the end, being poked-just like experiencing a microaggression-could be much more than a minor annoyance, having tangible and harmful consequences. Ultimately, no one wants to be poked all day, physically or verbally.

While the research literature is expanding, there is already evidence that microaggressions can lead to a range of psychological impacts that can impede learning, engagement, and belongingness in a scientific or academic setting (Torres and Driscoll, 2010; Wang et al., 2011). The most common impact that occurs is that the person-a student in a classroom or a research trainee in a laboratory setting-spends time and cognitive effort analyzing whether or not the microaggression actually occurred. While this may seem trivial, this mental analysis can take time and cognitive effort away from other tasks in which this person needs to engage in academic environments (Salvatore and Shelton, 2007; Bair and Steele, 2010). Further, the student or trainee is then confronted with the quandary of whether they should call out and address the microaggression. This decision requires even more attention and cognitive effort, and the thought of addressing the issue can also induce stress, especially if the microaggression originated from a person in a position of power (Clark et al., 1999; Torres and Driscoll, 2010; Mercer et al., 2011).

The presence of microaggressions can also trigger a phenomenon known as stereotype threat, in which individuals may worry about confirming a negative stereotype of their group in a situation in which they aspire to do well (Steele and Aronson, 1995; Steele, 1997; Aronson et al., 1999). When instances of stereotype threat occur, the individual under threat may find themselves in a tense situation in which they very much want to succeed, yet their worrying may lead to decreases in their performance, below what they have previously been shown to be capable of. Some observations suggest that these unexpected decreases in performance-underperformance due to stereotype threat-may be related to interference with working memory (Steele and Aronson, 1995; Steele, 1997; Aronson et al., 1999). As such, in high-pressure, scientific environments, experiencing stereotype threat may lead to significant, additional challenges for those trying to succeed in this setting. When someone is confronted with a microaggression that highlights a negative stereotype about some aspect of their personal identity, the experience may trigger stereotype threat and the unexpected underperformance that characterizes this phenomenon.

Microaggressions can also leave a person feeling isolated, especially if they are already a minority in a scientific environment. Such events can be especially detrimental when the individual is a member of an underrepresented group in that particular context. This feeling of isolation can lead to stress, anxiety, and depression (Wang et al., 2011; Nadal et al., 2014). All of these factors may lead a person-a student in an undergraduate science major or a scientific trainee in a research laboratory-to leave that isolating environment for another area of study that is more welcoming of their personal identity and members of their identity group.

Much of the research on microaggressions has been performed in relation to race and ethnicity. However, research into microaggressions related to other personal characteristics such as gender identity, sexual orientation, religious beliefs, and socioeconomic status is well under way, and many of the same principles appear to apply to these many other aspects of personal identity (Constantine, 2007; Sue et al., 2009; Capodilupo et al., 2010; Keller and Galgay, 2010; Owen et al., 2010; Nadal et al., 2011, 2012, 2013; Harwood et al., 2012; Huynh, 2012; Radmacher and Azmitia, 2013; Basford et al., 2014; Gonzales et al., 2015). As microaggression research expands, we are also becoming increasingly aware that the negative effects of microaggressions can be detrimental in populations that are currently understudied. For example, microaggressions may also affect dominant-culture students who are lost in the broader statistics of their group, although this effect may not be as visible. Perhaps they are the first in their family to go to college. Perhaps they are a Christian student dating a Muslim. Maybe their brother is transgender or their mother is schizophrenic. All of these personal characteristics, and many more, may not be readily visible but could still be aspects of an individual's personal identity that can be affected by the language of microaggressions (Lopez and Chims, 1993; Clair et al., 2005; McDermott and Samson, 2005; Beatty and Kirby, 2006; Radmacher and Azmitia, 2013). These students may deal with many of the same feelings of isolation, feel uncomfortable in an academic setting, and fail to achieve their full potential because of it. As such, we assert that it is critical that faculty should be aware of, and address, microaggressions directed at ALL students, not just certain groups of students.

\section{WHY MICROAGGRESSIONS MATTER, ESPECIALLY IN EFFORTS TO PROMOTE INCLUSION AND DIVERSITY IN THE SCIENCES}

Microaggressions may be an especially underappreciated factor in our current understanding of the impediments to increasing diversity in the sciences. Male faculty and students consistently underestimate female performance in the classroom (MossRacusin et al., 2012; Grunspan et al., 2016). And unwelcoming environments may lead underrepresented students to leave their undergraduate science studies at higher rates than their comparably talented peers (Seymour and Hewitt, 1994; Good, 2000). More generally, attrition rates are often higher in science, technology, engineering, and mathematics than other undergraduate majors, while entry rates are often low among 
general student populations (Green, 1989; Daempfle, 2003; Chang et al., 2014). As such, unwelcoming scientific environments may not only disproportionally affect groups of students underrepresented in science, but also have negative consequences for student populations as a whole. The extent to which microaggressions are present and influencing these situations is unclear.

And a lack of a welcoming scientific environment does not end in classrooms with students, but rather extends to the faculty level, where there is a lack of women and underrepresented minorities in leadership positions (Blickenstaff, 2005; Pololi et al., 2012, 2013; Rodriquez et al., 2016). Women and minority faculty cite issues with academic culture and recognition of their leadership skills as barriers to obtaining leadership positions and as reasons for leaving academia altogether (Pololi et al., 2012, 2013; Morley, 2013; Ford, 2016). In addition, women with similar qualifications are routinely rated lower than their male colleagues during the hiring process, and successful male faculty hire fewer women than men (Moss-Racusin et al., 2012; Sheltzer and Smith, 2014). The culture of science appears to have emerged as not welcoming to a majority of our society, and microaggressions may be a key variable in that culture.

So, how do we begin to improve the climate in science? While microaggressions may not be the sole cause of these climate issues, being aware of our use of language and acknowledging that what we say may have large impacts on our students and our colleagues, may be one possible avenue for improvement (Seidel et al., 2015). In addition to being aware of microaggressions, a few studies have also hypothesized that microaffirmations - small acts of language that foster inclusion, offer encouragement, and build relationships-may have a positive impact on academic climate (Rowe, 2008; Powell et al., 2013; Seidel et al., 2015). Studies of microaffirmations are only just beginning, but their potential for mitigating some of the negative outcomes of microaggressions warrant further attention.

\section{STRATEGIES FOR ADDRESSING MICROAGGRESSIONS}

Because it is important to acknowledge and address microaggressions, what are some ways in which we can begin to do so in our professional scientific contexts? There are several considerations when deciding how to address a microaggression. These include the severity of the microaggression, the context and culture, who generated the microaggression, and how hearing the microaggression may have affected those present.

Boysen (2012) identified several ways to address racial microaggressions in a classroom environment. These included direct confrontation, class discussion, private confrontation, and providing counterexamples (Boysen, 2012). Students in the study rated all of these methods as moderately effective. However, the makeup of the population, which was mostly white, may mask the relative effectiveness of these strategies (Boysen, 2012). In a separate study, Sue et al. (2009) used focus groups specifically with people of color to identify several strategies for addressing microaggressions. Most valued were those strategies that centered around making sure that the microaggression was acknowledged and taken seriously, that the topic was safe for discussion by all students involved, and that people's feelings were validated. Also, it was seen as critical that the discussion was legitimized and that students were not relied upon to be experts (Sue et al., 2009). As such, it is vital that the scientist in charge of the learning environment or laboratory setting take on a leadership role in responding to instances of microaggressive language.

Every context and situation is different, so ultimately there is no one solution for addressing microaggressions, but several key strategies from the research literature emerge as effective for mitigating the negative effects of microaggressions. First, acknowledging the microaggression is important for showing anyone affected that you are aware of the issue and that the potentially harmful situation is being given full consideration. Second, validating the negative feelings that can be caused by the microaggression is essential. Acknowledging the negative feelings that result from microaggressions can support those who may be affected, removing the cognitive load of having to analyze whether or not their feelings are valid (Gaztambide, 2012). Third, confronting the microaggressive language as having no place in academia is required to demonstrate aspirations to move away from this kind of language. Fourth, making oneself available to anyone affected by the microaggression shows that it is an issue that you take seriously and that the feelings of each person affected by the microaggression are important. Fifth, and finally, meeting privately with the person who initiated the microaggression, so as not to isolate them or make them feel resentful about how it was addressed, may be optimal. This may also double as an opportunity to support them in understanding how their language can be harmful to others, because the perceived aggressor may have had only good intentions.

Currently, there are no guidelines or research as to which strategies to use or in what order, and some may not be appropriate for every situation. Yet keeping these strategies in mind when faced with the difficult reality of microaggressions can provide opportunities for action. No situation will ever be handled perfectly. Often, awareness that a microaggression has occurred may not occur until it is identified by another individual, and it is still key to address the issue, because negative feelings brought on by microaggressions can linger and build up over time. By treating our students and colleagues with respect and compassion, we can create a more welcoming environment for everyone in science.

To help apply the ideas presented for addressing microaggressions, we highlight some potential ways in which these strategies could be used in three of the scenarios presented earlier. These strategies are not necessarily the most appropriate or only way to deal with the microaggressions in question, but rather are starting ideas on how to address a microaggression in a scientific context and not simply let such language occur without notice.

\section{Microassault: Dominique's Lab Meeting}

Dominique's PI is presenting an update on the state of research in a lab meeting when one of her colleagues, Ruth, in reference to an experiment not working, exclaims, "It's so gay that we can't get this assay to work correctly." Dominique's PI seems oblivious to the microaggression and continues with the presentation. One possible way Dominique could handle this scenario is to first politely stop the meeting to point out the sexual orientation microassault and inform Ruth that this type of language is not appreciated or productive. Dominique can then let the PI 
proceed with the meeting in whatever way the PI then chooses. It would also be helpful for Dominique to follow up with both Ruth and the PI in private. By following up with Ruth, Dominique may better support her in understanding the potential impacts of that type of language. Dominique may also want to meet with the PI to discuss how they might work together to foster a culture of inclusion in the laboratory and share why addressing such language in science is important.

\section{Microinsult: Jorge's Exam}

Jorge is teaching and has just handed back midterm exams for an introductory biology class. He hears a female student, Ashley, exclaim, “I didn't do well, but, oh well, girls aren't supposed to be good at science anyway, ha-ha." How should Jorge handle this microaggression example? In this case, one potential option for Jorge would be to call attention to this gender microinsult and make sure his students know that this is an issue he takes very seriously. Jorge could then lead a discussion in which he addresses this issue by bringing up the idea of stereotype threat and why this type of thinking is just not true. Then, Jorge could make himself available to any students who may need to discuss the issue further. It is generally important to address the microaggression privately with the individual from whom the language originated, but it may be even more crucial to do so in this case. Because the microaggression was in some sense self-inflicted, the language may reflect larger issues for which this student could use mentoring and support.

\section{Microinvalidation: Lisa's Faculty Meeting}

Lisa is in a biology faculty meeting when the topic of Black students not feeling comfortable in biology classrooms is raised. The chair of the department says this is cannot be an issue, because they have no issues with race in the department, and suggests the students just need to take better advantage of the resources on campus. This response seems to shut down any discussion, and several of Lisa's colleagues, including the only Black faculty member, look uncomfortable. In this situation, it may be too risky for Lisa to call out her chair in front of the rest of the department, but it is crucial that this racial microinvalidation not go unaddressed. In this situation, one option would be for Lisa to meet with her chair privately to address her concerns about the microaggression. Lisa can then attempt to clarify why this issue is still a problem, even if the chair does not see it as problematic. Lisa can then make herself available to meet with any of her colleagues who want to work on addressing the issue, including her Black faculty colleague.

\section{OPPORTUNITIES FOR NEW RESEARCH ON MICROAGGRESSIONS IN THE SCIENCES}

Given the emerging research on the presence and impact of microaggressions in other fields, it is clear that the everyday language used in scientific professional contexts does indeed matter, perhaps far more than has been acknowledged. As such, much more research on the presence and impact of microaggressions in the sciences is warranted. For example, how frequently, and to what extent do undergraduate students experience microaggressions in the context of their science courses? To what extent might the prevalence of microaggressive language vary across courses in different undergraduate science disciplines? Might the personal characteristic that is the focus of microaggressive language differ in different disciplines, for example, are there more gender microaggressions in the physical sciences? And how do the presence, frequency, and nature of microaggressions correlate with student achievement or performance gaps, as well as retention and graduation rates in these undergraduate majors?

Additionally, research on microagressions will need to extend beyond classroom contexts and into other scientific professional contexts, including research laboratories, lab group meetings, faculty meetings, and scientific conferences. To what extent can future research investigations detect microaggressions in these contexts, variation across the different contexts, and correlations with progress in the sciences toward promoting inclusion, equity, and diversity? Such investigations, situated squarely in the sciences, are likely highly relevant to persistent challenges in diversifying the sciences and are beginning to emerge (e.g., Anderson, 2017).

Finally, research is also needed to increase our understanding of a potentially key antidote to microaggressions, namely microaffirmations, which are purposefully positive and inclusive everyday language (Rowe, 2008; Powell et al., 2013; Seidel et al., 2015). In this piece, we have focused on explorations of microaggressions, for which there are currently more evidence and description. However, if language matters, then one would hypothesize that both positive (microaffirmative) and negative (microaggressive) language in professional contexts in science could be highly influential in promoting inclusion, sense of belonging, and success for all individuals who aspire to participate in the scientific enterprise. A research framework has recently emerged for investigating the noncontent languagenamely, anything said by an instructor that is not directly related to science content-used by undergraduate biology instructors (Seidel et al., 2015). This "instructor talk" framework may be methodologically useful for new research investigating both microaffirmations and microaggressions in the everyday language of scientific professional contexts. Recent investigations of the applicability of the instructor talk framework in dozens of new classroom contexts has shown that negative, nonproductive language related to existing framework categories is present, some of which may be considered microaggressions (C.H. and K.D.T., unpublished data).

\section{CONCLUSION}

Think back to when you may have felt slighted or invalidated by a casual comment by others related to an aspect of your personal identity. How might your experience have been different if you knew others around you would acknowledge and deal with the slight? Addressing microaggressions may at first feel overwhelming, but even small steps may be key in changing professional culture. Additionally, none of us want to think of ourselves as the kind of person who would say things that are hurtful to others. Yet all of us have likely produced microaggressions unintentionally, and increasing our attention to our language could help us avoid these situations. Identifying and addressing microaggressions in the everyday language of our scientific environments may be key to making our disciplines, our classrooms, our laboratories, and our conferences all professional contexts in which everyone can succeed. In fact, attending to inclusion, equity, and diversity in science is essential if we are committed to solving complex problems in the natural 
world and making exciting discoveries. Our language in interacting with one another along the way may prove to be a far more important variable than we have previously appreciated.

\section{ACKNOWLEDGMENTS}

We thank Jeff Shinske, Melinda Owens, Sarah Bissonnette, Kristen de Nesnera, Gloriana Trujillo, and Shannon Seidel for their feedback and discussion.

\section{REFERENCES}

Anderson, A. (2017). "It just weighs in the back of your mind": Microaggressions in science (College of Science and Health Theses and Dissertations 203). DePaul University, Chicago, IL. Retrieved October 7, 2017, from https://via.library.depaul.edu/csh_etd/203

Aronson, J., Lustina, M. J., Good, C., Keough, K., Steele, C. M., \& Brown, J. (1999). When white men can't do math: Necessary and sufficient factors in stereotype threat. Journal of Experimental Social Psychology, 35(1), $29-46$.

Bair, A. N., \& Steele, J. R. (2010). Examining the consequences of exposure to racism for the executive functioning of Black students. Journal of Experimental Social Psychology, 46, 127-132.

Basford, T. E., Offerman, L. R., \& Behrend, T. S. (2014). Do you see what I see? Perceptions of gender microaggressions in the workplace. Psychology of Women Quarterly, 38(3), 340-349.

Beatty, J. E., \& Kirby, S. L. (2006). Beyond the legal environment: How stigma influences invisible identity groups in the workplace. Employee Responsibilities and Rights Journal, 18(1), 29-44.

Blickenstaff, J. C. (2005). Women and science careers: Leaky pipeline or gender filter? Gender and Education, 17(4), 369-386

Boysen, G. (2012). Teacher and student perceptions of microaggressions in college classrooms. College Teaching, 60, 122-129.

Capodilupo, M. J., Nadal, K. L., Corman, L., Hamit, S., Lyons, O. B., \& Weinberg, A. (2010). The manifestation of gender microaggressions. In Sue, J. W. (Ed.), Microaggressions and marginality: Manifestation, dynamics, and impact (pp. 193-216). Hoboken, NJ: John Wiley \& Sons Inc.

Chang, M. J., Sharkness, J., Hurtado, S., \& Newman, C. B. (2014). What matters in college for retaining aspiring scientists and engineers from underrepresented racial groups. Journal of Research in Scientific Teaching, 51(5), 555-580

Clair, J. A., Beatty, J. E., \& Maclean, T. L. (2005). Out of sight but not out of mind: Managing invisible social identities in the workplace. Academy of Management Review, 30(1), 78-95.

Clark, R., Anderson, N. B., Clark, V. R., \& Williams, D. R. (1999). Racism as a stressor for African Americans: A biopsychosocial model. American Psychologist, 54, 805-816.

Constantine, M. (2007). Microaggressions against African American clients in cross-racial counseling relationships. Journal of Counseling Psychology. $54,1-16$

Daempfle, P. A. (2003). An analysis of the high attrition rates among first year college science, math, and engineering majors. Journal of College Student Retention: Research, Theory \& Practice, 5(1), 37-52.

Ford, L. E. (2016). Two steps forward, one step back? Strengthening the foundations of women's leadership in higher education. Politics, Groups, and Identities, 4(3), 499-512.

Gaztambide, D. J. (2012). Addressing cultural impasses with rupture resolution strategies: A proposal and recommendations. Professional Psychology: Research and Practice, 43(3), 183-189.

Gonzales, L., Davidoff, K. C., DeLuca, J. S., \& Yanos, P. T. (2015). The Mental Illness Microaggressions Scale-Perpetrator version (MIMS-P): Reliability and validity. Psychiatry Research, 229, 120-125

Good, J. M. (2000). A promising prospect for minority retention: Students becoming peer mentors. Journal of Negro Education, 69(4), 375-383.

Green, K. (1989). A profile of undergraduates in the sciences. American Scientist, 78, 475-480.

Grunspan, D. Z., Eddy, S. L., Brownell, S. E., Wiggins, B. L., Crowe, A. J., \& Goodreu, S. M. (2016). Males under-estimate academic performance of their female peers in undergraduate biology classrooms. PLoS One, 11(2), e0148405.

Harwood, S. A., Huntt, M. B., Mendenhall, R., \& Lewis, J. A. (2012). Racial microaggressions in the residence halls: Experiences of students of color at a predominantly white university. Journal of Diversity in Higher Education, 5(3), 159-173.

Huynh, V. W. (2012). Ethnic microaggressions and the depressive and somatic symptoms of Latino and Asian American adolescents. Journal of Youth and Adolescents, 41(7), 831-846.

Keller, R. M., \& Galgay, C. E. (2010). In Sue, J. W. (Ed.), Microaggressions and marginality: Manifestation, dynamics, and impact (pp. 241-267). Hoboken, $\mathrm{NJ}$ : John Wiley \& Sons Inc.

Lopez, G., \& Chims, N. (1993). Classroom concerns of gay and lesbian students: The invisible minority. College Teaching, 41(3), 97-103.

McDermott, M., \& Samson, F. L. (2005). White racial and ethnic identity in the United States. Annual Review of Sociology, 31, 245-261.

Mercer, S. H., Zeigler-Hill, V., Wallace, M., \& Hayes, D. M. (2011). Development and initial validation of the Inventory of Microaggressions Against Black Individuals. Journal of Counseling Psychology, 58, 457-469.

Morley, L. (2013). The rules of the game: Women and the leaderist turn in higher education. Gender and Education, 25(1), 116-131.

Moss-Racusin, C. A., Dovidio, J. F., Brescoll, V. L., Graham, M. J., \& Handelsman, J. (2012). Science faculty's subtle gender biases favor male students. Proceedings of the National Academy of Sciences USA, 109(41), 16474-16479

Murphy-Shigematsu, S. (2010). Microaggressions by supervisors of color Training and Education in Professional Psychology, 4(1), 16-18.

Nadal, K. L., Griffin, K. E., Hamit, S., Leon, J., Tobio, M., \& Rivera, D. P. (2012). Subtle and overt forms of Islamophobia: Microaggressions towards Muslim Americans. Journal of Muslim Mental Health, 4(2), 15-37.

Nadal, K. L., Issa, M., Leon, J., Meterko, V., Wideman, M., \& Wong, Y. (2011) Sexual orientation microaggressions: "death by a thousand cuts" for lesbian, gay, and bisexual youth. Journal of LGBT Youth, 8(3), 234-259.

Nadal, K. L., Sriken, J., Davidoff, K. C., Wong, Y., \& McLean, K. (2013). Microaggressions within families: Experiences of multiracial people. Family Relations, 62, 190-201.

Nadal, K. L., Wong, Y., Griffin, K. E., Davidoff, K., \& Sriken, J. (2014). The adverse impact of racial microaggressions on college students' self-esteem. Journal of College Student Development, 55(5), 461-474.

Owen, J., Tao, K., \& Rodolfa, E. (2010). Microaggressions and women in short-term psychotherapy: Initial evidence. Counseling Psychologist, 38 923-946.

Pierce, C., Carew, J., Pierce-Gonzalez, D., \& Willis, D. (1978). An experiment in racism: TV commercials. In Pierce, C. (Ed.), Television and education (pp. 62-88). Beverly Hills, CA: Sage.

Pololi, L. H., Civian, J. T., Brennan, R. T., Dotollo, A. L., \& Krupat, E. (2012) Experiencing the culture of academic medicine: Gender matters, a national study. Journal of General Internal Medicine, 28(2), 201-207.

Pololi, L. H., Evans, A. T., Gibbs, B. K., Krupat, E., Brennan, R. T., \& Civian, J. T. (2013). The experience of minority faculty who are underrepresented in medicine, at 26 representative U.S. medical schools. Academic Medicine, 88(9), 1308-1314.

Powell, C., Demetriou, C., \& Fisher, A. (2013). Micro-affirmations in academic advising: Small acts, big impact. Mentor: An Academic Advising Journal, 279(11), 2022-2035.

Radmacher, K., \& Azmitia, M. (2013). Unmasking class: How upwardly mobile poor and working-class emerging adults negotiate an "invisible" identity Emerging Adulthood, 1(4), 314-329.

Rodriquez, T. E., Zhang, M. B., Tucker-Lively, F. L., Ditmyer, M. M., Beck Brallier, L. G., Haden, N. K., \& Valachovic, R. W. (2016). Profile of department chairs in U.S. and Canadian dental schools. Demographics, Requirements for Success, and Professional Development Needs, 80(3), 365-373.

Rowe, M. (2008). Micro-affirmations and micro-inequities. Journal of the International Ombudsman Association, 1(1), 45-48.

Salvatore, J., \& Shelton, J. N. (2007). Cognitive costs of exposure to racial prejudice. Psychological Science, 18, 810-815.

Seidel, S. B., Reggi, A. L., Shinske, J. N., Burrus, L. W., \& Tanner, K. D. (2015). Beyond the biology: A systematic investigation of noncontent instructor 
talk in an introductory biology course. CBE-Life Sciences Education, 14(4), ar43.

Seymour, E., \& Hewitt, N. (1994). Talking about leaving: Factors contributing to high attrition rates among science, mathematics \& engineering undergraduate majors. Final Report to the Alfred P. Sloan Foundation, Boulder: University of Colorado, Ethnography and Assessment Research Bureau of Sociological Research.

Sheltzer, J. M., \& Smith, J. C. (2014). Elite male faculty in the life sciences employ fewer women. Proceedings of the National Academy of Sciences USA, 111(28), 10107-10112.

Steele, C. M. (1997). A threat in the air: How stereotypes shape intellectual identity and performance. American Psychologist, 52(6), 613-629.

Steele, C. M., \& Aronson, J. (1995). Stereotype threat and the intellectual test performance of African Americans. Journal of Personality and Social Psychology, 69(5), 797-811.

Sue, D. W. (2010). Microaggressions in everyday life: Race, gender, and sexual orientation. Hoboken, NJ: Wiley.
Sue, D. W., Bucceri, J., Kin, A. I., Nadal, K. L., \& Torino, G. C. (2007). Racial microaggressions and the Asian American experience. Cultural Diversity and Ethnic Minority Psychology, 13, 72-81.

Sue, D. W., Lin, A. I., Torino, G. C., Capodilupo, C. M., \& Rivera, D. P. (2009). Racial microaggressions and difficult dialogues on race in the classroom. Cultural Diversity and Ethnic Minority Psychology, 15(2), 183-190.

Times Editorial Board (2015, 24 June). UC system going the wrong way on free speech. Los Angeles Times.

Torres, L., \& Driscoll, M. W. (2010). Racial microaggressions and psychological functioning among highly achieving African-Americans: A mixed methods approach. Journal of Social and Clinical Psychology, 29, 1074-1099.

Wang, J., Leu, J., \& Shoda, Y. (2011). When the seemingly innocuous "stings": Racial microaggressions and their emotional consequences. Personality and Social Psychology Bulletin, 37(12), 1666-1678.

Zamudio-Suarez, F. (2016). What happens when your research is featured on "Fox \& Friends." Chronicle of Higher Education, Retrieved November 11, 2016, from www.chronicle.com/article/What-Happens-When-Your/236949 